\title{
Neisseria gonorrhoeae, Penicillinase Negative
}

National Cancer Institute

\section{Source}

National Cancer Institute. Neisseria gonorrhoeae, Penicillinase Negative. NCI Thesaurus.

Code C123527.

Any bacterial species identified as Neisseria gonorrhoeae that does not produce the enzyme penicillinase. 